https://doi.org/10.18485/iipe_euchanges.2021.ch3

\title{
SUPREMACY OF EU LAW OVER NATIONAL LEGISLATION AND SUPREME JURISDICTIONS OF THE MEMBER STATES - A QUEST FOR A NEW BALANCE
}

\author{
Uroš ĆEMALOVIĆ ${ }^{1}$
}

\begin{abstract}
The principle of the supremacy of EU law over national legislation is crucial for the viability of the Union's legal order, but also for the safeguard of some basic democratic values within the Member States themselves. Despite its global acceptance, some national courts of final instance keep challenging this principle, invoking complex reasoning that often includes multiple grounds for its refusal. Using mainly a content analysis of the case-law and comparative legal method, the paper examines the possibility of a new balance between the principle of the supremacy of EU law and the specificities of national legal orders. The preconditions for striking this new balance are threefold. First, the national courts should apply the concept of constitutional identity more carefully and in a more restrictive manner. Second, the EU law itself has to be formulated in better and clearer terms, as a result of a less cumbersome legislative process. Finally, without a less hesitant common approach of the European political elites in reforming its functioning, the weaknesses of the Union's institutional and decision-making architecture would continue to undermine its legal system.
\end{abstract}

Keywords: the supremacy of EU law, EU member states, Court of Justice of the EU, national legal orders, constitutional law, the rule of law.

\section{INTRODUCTION}

The supremacy (often referred to as 'precedence') of European Union (EU) law over national legislation of its member states is not only a well-

${ }^{1}$ Associate Professor; Doctor of the University of Strasbourg; Research Associate at the Institute of European Studies, Belgrade, Serbia. E-mail: contact@cemalovic.com 
established principle, but also a basic precondition for the good functioning of the Union's institutional system, and, consequently, the implementation of its numerous policies. The European Court of Justice (ECJ) (after the adoption of the Lisbon Treaty: Court of Justice of the European Union CJEU) started to establish this principle already from 1964, and the next decades have brought its significant deepening and strengthening. Consequently, the supremacy of EU law is applicable to both Union's primary and secondary legislation, while not only the decisions of all national courts, but also national constitutions of all Member States are subject to this principle. In such a context, the recent ruling of the German Federal Constitutional Court (Bundesverfassungsgericht - BVerfG) has profoundly questioned the principle of the supremacy of EU law, creating turmoil among judges, legal experts, scientists, but also decision-makers within both the EU and its member states. Moreover, the institutions of some EU Member States have recently adopted legal acts and political decisions - often not restraining from directly invoking the inclination towards 'illiberal democracy' ${ }^{2}$ - detrimental to the rule of law, independent judiciary ${ }^{3}$ and freedom of media, potentially breaching the EU's core values. ${ }^{4}$

Using mainly the content analysis of the case-law and comparative legal method, the author argues that the judicial origin and the unclearly formulated content of the principle of supremacy significantly undermines its raison d'être, allowing uncertainty and politicisation. As the global public health crisis caused by the COVID-19 outbreak has shown, all actions taken by EU Member States to address it 'have had an impact to a lesser or greater degree on democracy, the rule of law and human rights,' creating a potentially detrimental context to both national and the EU legal order

${ }^{2}$ For the notion of 'illiberal democracy', see (Pap, 2019); for a wider comparative overview, see (Madariaga, 2020).

${ }^{3}$ On 29 April 2020, the European Commission has launched an infringement procedure against Poland regarding the new law on the judiciary of 20 December 2019, which entered into force on 14 February 2020, estimating that 'the new law on the judiciary undermines the judicial independence of Polish judges and is incompatible with the primacy of EU law'; for more details, see https:/ / ec.europa. eu/commission/presscorner/detail/en/ip_20_772. Accessed on 31 January 2021.

${ }^{4}$ In its resolution adopted on 16 January 2020 (with 446 votes to 178 and 41 abstentions), the European Parliament indicated that, when it comes to the rule of law, 'the situation in both Poland and Hungary has deteriorated'; for more details, see https:/ / www.europarl.europa.eu/news/en/press-room/20200109IPR69907/ rule-of-law-in-poland-and-hungary-has-worsened. Accessed on 31 January 2021. 
(European Commission for Democracy Through Law (Venice Commission), 2020). Therefore, the paper examines the possibility of a new balance between the principle of the supremacy of EU law, on the one hand, and the specificities of national legal orders, on the other (Chapter 4).To do so, it is first necessary to analyse the content and substance of the principle of supremacy, as it is at the beginning of the third decade of the $21^{\text {st }}$ century (Chapter 2), before turning to the question of the acceptance (or not) of this principle by the supreme and/or constitutional jurisdictions of the EU Member States, including notably the judgement of the German BVerfGof 5 May 2020 (Chapter 3).

\section{SUPREMACY OF EU LAW-THE CURRENT CONTENT OF THE PRINCIPLE ${ }^{5}$}

The supremacy that EU law holds over all legal provisions belonging to the internal legal orders of its Member States has never been clearly defined in whichever multilateral legal act of EU primary law. In other words, all international treaties that have progressively established what the Union is nowadays - from the early 50s to the Treaties on EU(TEU) and the functioning of the EU (TFEU) adopted a decade ago - omitted to formulate an unambiguous provision dedicated to the supremacy of EU law. The only exception was the failed attempt to adopt the Treaty establishing a Constitution for Europe, ${ }^{6}$ whose Article 10 provided that 'the Constitution and law adopted by the institutions of the Union in exercising competences conferred on it shall have primacy over the law of Member States' (Draft Treaty Establishing a Constitution for Europe, 2003). Therefore, in the silence of primary law, the principle of the EU supremacy

\footnotetext{
${ }^{5}$ Wherever in this article it is referred to the period before entry into force of the Lisbon Treaty (1 December 2009), the notions of (European) Community and Community law will be systematically used. However, in order to facilitate the readability, the notion of supremacy of EU law (and not supremacy of Community law) will be usedwhen referring to the case-law adopted when the European Community still existed.

${ }^{6}$ This act was elaborated by the Convention presided by the former French President Valéry Giscard d'Estaing, and, on 29 October 2004,all twenty-five member states of the EU signed it. However, the document was refused in late May and early June2005 referendums in France and Netherlands. For a detailed overview, see (Laursen, 2008).
} 
was the fruit of a progressive and laborious interpretation by the ECJ/CJEU. Even if it can be argued that the Court of Justice established the principle of the supremacy 'very quickly' (Rideau, 2006, p. 913), it is clear that 'its judicial consecration was progressive' (Ćemalović\&Vukadinović, 2018, p. 40) and that it continues to be invoked in the case-law and analysed by academics. The first definition of what the ECJ referred to as the precedence of Community law' can be found in its prominent judgment of 15 July1964 (case Flaminio Costa v. ENEL). The Court's affirmation that 'the law stemming from the Treaty, an independent source of law, could not, because of its special and original nature, be overridden by domestic legal provisions, however framed, without being deprived of its character as Community law' (ECJ, 1964, p. 1160), has not only given rise to abundant writings in legal and political sciences, but was a starting point for a prolific case-law ${ }^{7}$ in this matter. The ramifications of the principle of the supremacy of EU law are numerous, but the one that bears special importance for our topic is its applicability to the internal constitutional provisions of the Member States. Only six years after its judgement in case Flaminio Costa $v$. $E N E L$, the ECJ added yet another crucial element leading to the solidification of the Community (now: the EU) as a sui generis entity, with a specific legal order and competences, differing in many aspects from classical international organisations. In its judgment of 17 December 1970 (case Internationale Handelsgesellschaft), the ECJ has set the basis allowing the supremacy of EU law over national constitutional provisions of the Member States. However it might have seemed shocking for some conservative constitutionalists, by affirming that the validity of a Community measure or its effect within a member state cannot be affected by allegations that it runs counter either fundamental rights as formulated by the constitution of the State or the principles of a national constitutional structure,' (ECJ, 1970, p. 532) the Court initiated a new era in the relations between, on the one hand, national internal legal orders and, on the other, the EU legal order.

As sufficient as it may seem, the content of the principle of the supremacy of EU law - as it was defined in two famous judgements from 1964 and 1970 - was further consolidated by case-law. The most important question to be answered is related to the status of a provision of national

\footnotetext{
${ }^{7}$ For example, the most recent judgement of the CJEU mentioning expressis verbis 'the principle of the precedence of EU law' was taken on 1 October 2020 (case C603/19 - Urad špeciálnej prokuratúry).
} 
law that is incompatible with EU law. Already from $1978,{ }^{8}$ the Court's wellestablished and often reiterated interpretation is that the national court is obliged 'within the exercise of its jurisdiction, to apply the provisions of EU law and to give full effect to those provisions by refusing to apply any provision of national law which would lead that court to deliver a decision contrary to EU law' (CJEU, 2016, para. 32). Moreover, the Court introduced some additional principles that could not be seen as an element of the supremacy of EU law strico sensu, but whose application by national courts of the Member States solidifies the Union's legal order. It is, especially, the case of the principle of effectiveness, ${ }^{9}$ according to which the institutions of the Member States, when they act in the limits of their competences, should not do so in a way to 'render impossible in practice or excessively difficult the exercise of rights conferred by the European Union legal order' (CJEU, 2012, para. 45). In other words, the national competences should not be exercised in a way that practically undermines the provisions of EU law, the principle that could also be seen as an indirect consequence of their supremacy over provisions of national laws. Therefore, the principle of effectiveness is, to a certain extent, the application to the Member States of old Roman civil law maxim Nemo auditur.

Even though the principle of the supremacy of EU law was first formulated almost six decades ago, the CJEU keeps invoking it quite regularly in its recent acts. For example, over the period of the last five years (1 January 2016 - 31 December 2020), the term precedence of EU law was mentioned in two judgments (CJEU, judgments in Ince (C-336/14) and C603/19) and one opinion of the Advocate General (Opinion of AG Kokott in Association France Nature Environnement v. Premier ministre (C-379/15), while, in the same time span, the notion supremacy of EU law appears in three opinions of three different Advocates General of the CJEU (Opinion of AG Hogan in Generalstaatsanwaltschaft Berlin(C-398-19) AG Wathelet in Slowakische Republik v. Achmea BV(C-284/16) and AG Bot in Beshkov (C$171 / 16)$ ). In the same vein, contemporary legal doctrine keeps referring to this principle, underlying its 'evolutionary nature' (Craig\&de Búrca, 2020,

${ }^{8}$ The inapplicability of any provision of the national legal order that is contrary to Community law is first mentioned in the ECJ's judgment of 9 March 1978 in Simmenthal (106/77, para. 21-23).

${ }^{9}$ This principle appears more often in the ECJ's judgements from the middle of the 90s, like, for example, in Peterbroeck (C-312/93, para.12) and Preston and Others (C78/98, para. 31). 
p. 317) and affirming that it ensures 'the equality of the member states before the law, preventing each country of the EU from cherry-picking which provisions of EU it likes or not' (Fabbrini, 2015, p. 1003). However, while the content of the principle of the supremacy of EU law - after decades of its progressive elaboration by the ECJ/CJEU - may be seen as clear and stabilised, it is far from being the case when it comes to its acceptance by the national supreme and constitutional courts.

\section{ACCEPTANCE OF THE SUPREMACY OF EU LAW BETWEEN LAW AND POLITICS}

If there would be a list of statements for which the judges of constitutional and supreme courts share unequivocal and profound disdain, the one that certain meta-legal factors could interfere with their reasoning and decision-making will certainly figure very high on it. It is, of course, undoubtedly justified when judges believe that in their decisions they only 'stick to the law' and even more when they actually do so. However, if, for example, a supreme court rejects the supremacy of EU law by reference to a vague and highly politicised concept such as the will of the national legislator,' it clearly makes a choice not the apply EU law by giving preeminence to the value it sees as crucial within its own internal national legal order. Without pretension to be exhaustive, this chapter will try and distil the reasoning of various national courts when they refuse to accept the supremacy of EU law, with a focus on the most recent of such decisions.

The reference to their national constitutional norms is the most common and the most general ground upon which the supreme and/or constitutional courts of the Members States refuse or limit the supremacy of EU law; in other words, by doing so, the judges in the Member States refuse to accept the ECJ's judgment in Internationale Handelsgesellschaft and further case-law based upon it. However, the refusal by a national supreme court to apply EU law could also result from its opinion that the Union, when adopting this legislation, did not act within the limits of its own competence, while, in some cases, a national court could also refers to certain national legal, doctrinal (or even political) concepts. One of the recent examples is the ruling of the Supreme Court of Denmark in Ajos (Supreme Court of Denmark, 2014) in which it refused to apply the CJEU's case law on age discrimination, given that it would, inter alia, contradict the will of the national legislator. This ruling is often seen as a prominent example of the limitation of the supremacy of EU law on the basis of national 
(constitutional) identity (Dougan, 2020, p. 4), as well as a possible indication of a 'new sovereigntism in Danish law that is at odds with the project of European integration through law' (Madsen et all., 2017, p. 140). In any case, the reasoning of the national courts of the final instance, when they refuse the supremacy of EU law, is complex and multifaceted, often including multiple grounds for this refusal. It is, though, particularly interesting - as the example of the ruling of the German BVerfG of 5 May 2020 clearly shows - when the national court invokes the illegality of a CJEU ruling as a reason for its disregard in the national legal system. ${ }^{10}$

In the context of its policy of quantitative easing, back in 2015, the European Central (ECB) Bank adopted the so-called Public Sector Purchase Programme (PSPP), ${ }_{11}^{11}$ a crucial part of a larger initiative known as the Extended Asset Purchase Programme. On 11 January 2017 - after four national constitutional actions brought, among others, by a well-known businessman Heinrich Weiss, but also by Peter Gauweiler, a former leader of the German conservative party CSU - the BVerfG made a request before the CJEU for a preliminary ruling regarding the validity of the Decision the $\mathrm{ECB}^{12}$ of 4 March 2015. In its judgement in this case (Weiss) (CJEU, 2018, 1000), the CJEU concluded that the measures taken by the ECB were adopted within the limits of its competence ${ }^{13}$ and proportional in relation to the objectives of monetary policy. However, in its judgment of 5 May 2020 (BVerfG, 2020)

${ }^{10}$ Given that this situation includes two courts of the last instance - in a way that a national court questions the legality of the CJEU ruling - doctrine often refers to it as a 'clash of the titans'; see, for example (Gualco, 2017), (Orešković, 2020).

11 This programme was introduced by the Decision (EU) 2015/774 of the ECB of 4 March 2015 on a secondary markets public sector asset purchase programme (OJ 2015 L121, p. 20). The PSPP consists of the purchase of bonds issued by euro area central governments, agencies and European institutions, but also of bonds issued by regional and local governments; for more, see Public Sector Purchase Programme, Questions and Answers, European Central Bank, https:/ / www.ecb. europa.eu/mopo/implement/app/html/pspp-qa.en.html and Public Sector Purchase Programme, Deutsche Bundesbank https://www.bundesbank.de/ en/tasks/monetary-policy/outright-transactions/public-sector-purchaseprogramme-pspp-831140. Accessed on 9 January 2021.

${ }^{12}$ See previous footnote.

${ }^{13}$ More specifically, at issue were, inter alia, the questions whether the ECB was acting within the sphere of monetary policy, and whether its Decision 2015/774 is compatible with Article 123-1 of the Treaty on the Functioning of the EU; the CJEU has responded positively to both questions (see para. 53-70 and 101-108). 
the BVerfG declared that the CJEU's preliminary ruling in Weiss was ultra vires, due to the inadequate proportionality assessment of the ECB's measures. It is exactly in this point that lie the two most important - and, for the future of the EU's institutional and political specificity, potentially the most far-reaching -characteristics of the BVerfG's legal reasoning.

First, the BVerfG not only held a judgment of the CJEU to be ultra vires, but also did so in a matter of the legality of the act of an EU institution. Before the BVerfG's ruling of 5 May 2020, some other national constitutional courts were adopting similar decisions, as it was, for example, the judgement of the Czech Constitutional Court (CCC) of 31 January 2012 in Slovak pensions (Constitutional Court of the Czech Republic, 2012), in which it held ultra vires - and, thus, inapplicable - the earlier judgement of the CJEU in Landtová (CJEU, 2011). However, the 2012 CCC's decision was taken in the context 'of the uniqueness of the issue of pension claims associated with the dissolution of the Czechoslovak state and the need to resolve it within bilateral Czech-Slovak relations'(Pítrová, 2013, p. 101). On the other hand, 'the German Court unilaterally granted itself the power to decide on the validity within Germany of the PSPP decision of the ECB, an EU institution under the exclusive jurisdiction of the CJEU' (Walsh, 2020).While the CCC's judgement could be considered as an example of a single-layered breach of the principle of the supremacy of EU law, the BVerfG's ruling is an example of a heavier, double-layered disregard for the Union's legal order: the Constitutional Court of a Member State held that the EU's supreme court was wrong in a matter regarding an act adopted by another EU institution, whose legality the former is exclusively entitled to examine.

Second, in its recent decision, the BVerfG went a step further from its own earlier interpretation that it has the jurisdiction to consider the validity of EU legislation in Germany. The important part of the BVerfG's reasoning in the ruling of 5 May 2020 relies on the criticism of the ECB's methodology and approach to proportionality, issues that are at the core of the ECB's institutional autonomy. By stating that, 'in view of the considerable economic policy effects resulting from the PSPP [...] it would have been incumbent upon the ECB to weigh these effects and balance them, based on proportionality considerations,' and, notably, by affirming that 'it is not ascertainable that any such balancing was conducted,' the BVerfG largely overstepped its mission and competences (BVerfG, 2020). Not only that 'this demanding approach of proportionality contained in the judgment of the constitutional court goes well beyond what has come to be accepted as necessary to satisfy the principle,' (Walsh, 2020) and, thus, is tainted by 
illegality; the judges also 'make manifest errors in applying the principle of proportionality to the delimitation of competences between the Union and the Member States' (Ziller, 2020), undermining the primacy of EU law in a matter essentially unrelated to national constitutional law. However, the challenges and possible consequences of the BVerfG's judgement are mainly political. ${ }^{14}$ First, by 'putting in question the legitimacy of a current ECB's policy' (Zarka, 2020), the German Constitutional Court effectively undermines the Bank's independence. Second, by departing from the CJEU's preliminary ruling on the very same issue, 'it arrogates to itself the power to make a final assessment of the legality of an act of the European Union' (Ziller, 2020), thus challenging not only the Union's legal order, but also its institutional viability. Finally, it is highly ironic that - by affirming the ECB's decisions are excessively limiting the powers of the national legislator and, thus, contrary to the principle of democracy - the BVerfG opens the way for much stronger national influence of 'refurbished authoritarian tendencies in some EU countries,' (Ćemalović, 2020a, p 186) allowing the potential strengthening of a more substantial disregard for the rule of law within the internal legal orders of some other Member States.

\section{TOWARDS A NEW BALANCE BETWEEN THE PRINCIPLE OF THE SUPREMACY OF EU LAW AND THE SPECIFICITIES OF NATIONAL LEGAL ORDERS}

As the previous chapter endeavoured to demonstrate, the acceptance of the principle of the supremacy of EU law is not only crucial for the viability of the Union's legal order, but also for the safeguard of basic democratic values within the Member States. In other words, the argumentation of the BVerfG related to the 'principle of democracy' reduced to the will of the national legislator 'would in fact justify the refusal of governments such as that of Hungary or Poland, which have a comfortable majority in Parliament, to apply

${ }^{14}$ An additional proof to which extent the BVerfG's judgement of 5 May 2020 became a highly politicised issue is the parliamentary question of several members of the European Parliament of 20 July 2020, in which they ask if (and when) the Commission intends to open an infringement procedure against Germany because of this judgement, see Parliamentary Questions, Priority question for written answer P-004295/2020 to the Commission, retrieved from https:// www.europarl.europa.eu/doceo/document/P-9-2020-004295_EN.html. Accessed on 13 January 2021. 
the judgments of the Court of Justice condemning them for violation of Article 19TEU by their actions that call into question the independence of the judiciary' (Ziller, 2020). On the other hand, a systematic disregard of the supremacy of EU law by the national supreme or constitutional courts would seriously undermine its uniform application in different Member States, putting their citizens in an unequal position. This is why some judges of the highest national courts propose different strategies for 'avoiding, minimising and resolving' (Dimitrakopoulos, 2019, p. 6) potential conflicts between national constitutional law and EU law. However, striking a new balance between EU law and internal legal orders should not rely upon simple casuistic conflict avoiding, but also has to include some general principles, based upon identifying the overarching causes of this conflict, if and when it appears.

It should be first noted that, in numerous national legal orders, the acceptance of the principle of the supremacy of EU law has never been a problem, either because it is 'recently reaffirmed' (Díaz-Asensio and Calvo, 2020, p. 460) by constitutional judges - or even considered by them as 'the most important fundamental principle of the EU' (Trstenjak\&Weingerl, 2020, p. 478) - or simply since the issue has not been raised (Radu, 2020, p. 431). In some countries, despite the fact that the constitutional court formally proclaimed the supremacy of the constitution over EU law, in practice, the judiciary 'has recognised the supremacy of EU law over national law and its obligation to apply it' (Bačić Selanec et all., 2020, p. 116). However, in some Member States, the resistance to recognise the primacy of EU law over national constitutions is not only the result of the decisions of the highest national courts, but also 'the result of a non-cooperative attitude of the actors responsible at the national level and an expression of the misunderstanding of the relationship between the national judicial system and the EU courts' (Pítrová, 2013, p. 101). Therefore, the acceptance of the supremacy of EU law encounters the following two overarching problems. First, the internal legal and judicial systems - as well as the doctrine and overall national 'legal

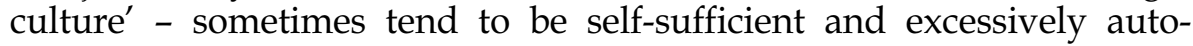
referential, while the sui generis character of the EU and its legal system requires more adapted approaches. Second, EU law as such is often either incomplete or formulated in ambiguous terms, ${ }^{15}$ thus allowing its

${ }^{15}$ A good and recent example of a piece of EU legislation that would, most certainly, provoke numerous problems in its implementation is Directive 2019/790 of 17 April 2019 on copyright and related rights in the Digital Single Market, that it has to be transposed by the Member States no later than 7 June 2021; for more details, see (Ćemalović, 2020b). 
inconsistent application by various instances within the Member States. In the same vein, finding a new balance between, on the one hand, the supremacy of EU law and, on the other, national legal orders, requires the efforts of Member States' institutions, but also of the Union's policymakers.

Whenever the CJEU has given a judgement on a matter related to the interpretation of EU law, the obligation of the national judicial systems to follow it is not only the question of the viability and integrity of the Union's legal order; the equality of the Member States, but also of their citizens, critically depends on it. The special responsibility in this matter relies on the national supreme and constitutional courts, the majority of which (National Courts and the Enforcement of EU Law: The Pivotal Role of National Courts in the EU Legal Order, 2020) either expressis verbis or indirectly -have recognized and applied the supremacy of EU law, the approach that should be their 'normal course of action' (Dimitrakopoulos, 2019, p. 6). Even though national constitutional courts can, to a certain extent, apply identity control tests to EU acts under the clause of Article 4(2) TEU, 'the abuse of constitutional identity and constitutional pluralism by the Hungarian, the Polish or any other constitutional court is nothing but national constitutional parochialism, which attempts to abandon the common European constitutional whole, and is inconsistent with the requirement of sincere cooperation of Article 4(3) TEU' (Halmai, 2018, p. 6). Therefore, as it was indicated in the previous chapter regarding the potential outcomes of the BVerfG's judgement of 5 May 2020, the rule of law within the Member States themselves could be seriously undermined by departing from the CJEU's judgements and more generally, by disregarding the supremacy of EU law in the matters of the Union's competence.

The good and consistent application of EU law in the Member States is far from depending solely on some heavy and sophisticated reasoning related either to the notions such as 'constitutional pluralism, the network concept, multilevel constitutionalism and composite constitutionalism' (Halmai 2018, p. 1) or to the laborious distinctions between relative or absolute supremacy of the EU. Very often, EU law would have been applied much more effectively and consistently by various (not only judicial) national instances if it had been formulated in better and clearer terms. The absence of a definition of the supremacy of EU law from the treaties already mentioned in chapter 2 of this paper - is just one side of the coin, the other being the over-complexity of EU's law-making process, and its policy-making based on 'the search for the smallest common denominator leading to empty political verbiage' (Ćemalović, 2020a, p. 189). In other 
words, the entire EU legal order and, consequently, the principle of its supremacy over national legislation, suffer a lot because of the weaknesses of institutional and decision-making architecture of the Union. Given that the global crisis caused by the COVID-19 pandemic was not an ideal context for any substantial reforms, it remains to be seen whether the EU legal order will continue to be a hostage of both Union's cumbersome law-making process and its hesitant political elites.

\section{CONCLUSION}

The principle of the supremacy of EU law was established almost six decades ago, and its content is globally clear and stabilised. The recent judgements of the CJEU are invoking it quite regularly, while the contemporary legal doctrine keeps referring to its 'evolutionary nature, 'disserting about the relative or absolute validity of this supremacy. However, even though in numerous national legal orders the acceptance of the principle of the supremacy of EU law has never been an issue, the constitutional courts in some EU countries are considerably limiting its effects, putting in danger not only the equality of the Member States and its citizens, but also opening a way for more substantial disregard for the rule of law on the national level. Apart from representing a heavier, doublelayered disregard for the EU legal order, the BVerfG's judgement of 5 May 2020 , could, quite ironically, by reducing the 'principle of democracy' to the will of the national legislator, contribute to undermining democracy in some other Member States. However, striking a new balance between the principle of the supremacy of EU law and the specificities of internal legal orders does not rely solely on the national instances. First, it would be highly beneficial - both for the EU legal order and for the rule of law within the Member States - if the national courts would apply the concept of constitutional identity more carefully and in a more restrictive manner. Second, EU law would have been applied much more effectively and consistently by various (not only judicial) national instances if it had been formulated in better and clearer terms, as a result of a less cumbersome legislative process. Finally, without a less hesitant common approach of the European political elites in reforming its functioning, the weaknesses of the Union's institutional and decision-making architecture would continue to undermine its legal system. 


\section{REFERENCES}

Bačić Selanec N. et all. (2020). Report on Croatia, in: National Courts and the Enforcement of EU Law: The Pivotal Role of National Courts in the EU Legal Order, XXIX FIDE Congress Publications, pp. 115-132, The Hague, Eleven.

BVerfG, Judgment of the Second Senate of 5 May 2020 (2 BvR 859/15), retrieved from https://www.bundesverfassungsgericht.de/Shared Docs/Entscheidungen/EN/2020/05/rs20200505_2bvr085915en.html, accessed 13 January 2021.

Ćemalović, U. \&Vukadinović, A. (2018). The Specificity of European Union's Legal System - Aspects Related to the Principles of Primacy and Direct Effect, Journal of Social Sciences, 1 (10), pp. 38-62.

Ćemalović. U. (2020a). One Step Forward, Two Steps Back: The EU and the Western Balkans After the Adoption of the New Enlargement Methodology and the Conclusions of the Zagreb Summit, Croatian Yearbook of European Law and Policy, 16, pp. 179-196.

Ćemalović. U. (2020b). Creativity and Ownership: Protection of Rights in Musical Works in the European Union From Digitisation to Artificial Intelligence, Musicology, 29, pp. 149-162.

CJEU, judgement of 22 June 2011 in Marie Landtová v. Českás práva socialního zabezpečení (C-399/09), ECLI:EU:C:2011:415.

CJEU, judgment in Association France Nature Environnement v. Premier minister, 2016, (C-379/16).

CJEU, judgment in Inter-Environnement Wallonie ASBL, Terre wallonne ASBL v. Régionwallonne, 2012, (C-41/11).

CJEU, judgment of 11 December 2018 (C-493/17), ECLI:EU:C:2018:1000.

Constitutional Court of the Czech Republic, judgement of 31 January 2012 (case Pl. ÚS 5/12).

Craig, P. \&de Búrca, G. (2020). EU Law - Text, Cases and Materials. Oxford, Oxford University Press.

Decision (EU) 2015/774 of the European Central Bank of 4 March 2015 on a secondary markets public sector asset purchase programme (ECB/2015/10), OJ L 121.

Díaz-Asensio, J.A.\&Calvo, M.P. (2020). Report on Spain, in: National Courts and the Enforcement of EU Law: The Pivotal Role of National Courts in the 
EU Legal Order, XXIX FIDE Congress Publications (pp. 459-474). The Hague, Eleven.

Dimitrakopoulos, I. (2019). Conflicts between EU law and National Constitutional Law in the Field of Fundamental Rights, European judicial training network, retrieved from http:/ / www.ejtn.eu/PageFiles/17318/ DIMITRAKOPOULOS\%20Conflicts\%20between\%20EU\%20law\%20and \%20National\%20Constitutional\%20Law.pdf. Accessed 15 January 2021.

Dougan, M. (2020). National Courts and the Enforcement of EU Law, in: National Courts and the Enforcement of EU Law: The Pivotal Role of National Courts in the EU Legal Order, XXIX FIDE Congress Publications (pp. 2937). The Hague, Eleven.

Draft Treaty Establishing a Constitution for Europe, Official Journal of the European Union C 169 (2003) 1-150.

ECJ, judgment Flaminio Costa v. ENEL (case 6/64), 1964, Col. p. 1160

ECJ, judgment in Internationale Handelsgesellschaft GmbH v. Einfuhr-und für Vorratsstelle Getreide und Futtermittel, 1970 (case 11-70), Col. p. 532.

European Commission for Democracy Through Law (Venice Commission), Interim report on the measures taken in the EU Member States as a result of the COVID-19 crisis and their impact on democracy, the rule of law and fundamental rights, adopted on 9 October 2020, retrieved from https://www.venice.coe.int/webforms/documents/default.aspx?pdffi le=CDL-AD(2020)018-e. Accesed 31 January 20210.

Fabbrini, F. (2015). After the OMT Case: The Supremacy of EU Law as the Guarantee of the Equality of the Member States, German Law Journal, 16(4), pp. 1003-1023.

Gualco, E. (2017). 'Clash of Titans' 2.0. From Conflicting EU General Principles to Conflicting Jurisdictional Authorities: The Court of Justice and the Danish Supreme Court in the Dansk Industri Case, European Papers, retrieved from https:/ / www.europeanpapers.eu/en/europeanforum/clash-of-titans-2-0-from-conflicting-eu-general-principles-toconflicting-jurisdictional-authorities. Accessed 8 January 2021.

Halmai, G. (2018). Absolute Primacy of EU Law vs. Pluralism: the Role of Courts, retrieved from https://me.eui.eu/wp-content/uploads/sites/ 385/2018/05/IJPL_Special_Issue_Concluding_remarks_Halmai_final.p df. Accessed 15 January 2021.

Laursen, F. (ed.) (2008). The Rise and Fall of the EU's Constitutional Treaty. Leiden, Martinus Nijhoff Publishers. 
Madariaga, A. (2020). Neoliberal Resilience: Lessons in Democracy and Development from Latin America and Eastern Europe. Princeton, Princeton University Press.

Madsen, M., Olsen, H. \&Sadl, U. (2017). Competing Supremacies and Clashing Institutional Rationalities: The Danish Supreme Court's Decision in the Ajos Case and the National Limits of Judicial Cooperation, European Law Journal, 23 (1-2), pp. 140-150.

National Courts and the Enforcement of EU Law: The Pivotal Role of National Courts in the EU Legal Order, 2020, The Hague, Eleven.

Orešković, L. (2020). Clash of the Titans: The Impact of Weiss on the Future of Judicial Conflicts in the EU, Croatian Yearbook of European Law and Policy, 16, pp. 245-277.

Pap, A. (2019). Decline in Hungary: Law and Society in an Illiberal Democracy. Abingdon, Routledge.

Parliamentary Questions, Priority question for written answer P004295/2020 to the Commission, retrieved from https:/ / www.europarl. europa.eu/doceo/document/P-9-2020-004295_EN.html. Accessed 13 January 2021.

Pítrová, L. (2013). The judgement of the Czech Constitutional Court in the 'Slovak pensions' case and its possible consequences (in light of the 'fortiter in re suaviter in modo' principle), Právník, 2/2013, pp. 86-101.

Public Sector Purchase Programme, Deutsche Bundesbank, retrieved from https://www.bundesbank.de/en/tasks/monetary-policy/outrighttransactions/public-sector-purchase-programme-pspp-831140. Accessed 9 January 2021.

Public Sector Purchase Programme, Questions and Answers, European Central Bank, retrieved from https://www.ecb.europa.eu/mopo/ implement/app/html/pspp-qa.en.html. Accessed 9 January 2021.

Radu, R.H. (2020). Report on Romania, in: National Courts and the Enforcement of EU Law: The Pivotal Role of National Courts in the EU Legal Order, XXIX FIDE Congress Publications (pp. 429-434). The Hague, Eleven.

Rideau, J. (2006). Droit institutionnel de l'Union et des Communautés européennes. Paris, LGDJ.

Rule of law in Poland and Hungary has worsened, retrieved from https:/ / www.europarl.europa.eu/news/en/press-room/20200109IPR69907/ rule-of-law-in-poland-and-hungary-has-worsened. Accesed on 31 January 2021. 
Rule of Law: European Commission launches infringement procedure to safeguard the independence of judges in Poland, retrieved from https://ec.europa.eu/commission/presscorner/detail/en/ip_20_772. Accessed on 31 January 2021.

Supreme Court of Denmark, judgment of 6 December 2016 DI acting on behalf of Ajos A/S v. Estate of A.(case 15/2014).

Trstenjak, V.\&Weingerl, P. (2020). Report on Slovenia, in: National Courts and the Enforcement of EU Law: The Pivotal Role of National Courts in the EU Legal Order, XXIX FIDE Congress Publications(pp. 443-458). The Hague, Eleven.

Walsh, J. (2020). BVer Judgment of the Second Senate German Constitutional Court 5 May 2020 2BvR 859/15, retrieved from https://insights. doughtystreet.co.uk/post/102g990/. Accessed 11 January 2021.

Zarka, J-C. (2020). L'arrêt du 5 mai 2020 de la Cour constitutionnel le fédéraled' Allemagne concernant le programme PSPP de la Banque central eeuropéenne, Lextenso7-2020, retrieved from https:/ / www.actujuridique.fr/international/international-etrangers/droits-europeenue/larret-du-5-mai-2020-de-la-cour-constitutionnelle-federale-dallemag ne-concernant-le-programme-pspp-de-la-banque-centrale-europeenne/. Accessed 12 January 2021.

Zeiler, J. (2020). The Unbearable Heaviness of the German Constitutional Judge on the Judgment of the Second Chamber of the German Federal Constitutional Court of 5 May 2020 Concerning the European Central Bank's PSPP Programme, retrieved from http://dx.doi.org/10.2139/ ssrn.3598179. Accessed 13 January 2021. 